
\title{
Research Suare \\ Rapid Electrification in Kenya: Progress, challenges, and practical geospatial solutions
}

\author{
Alycia Leonard ( $\nabla$ alycia.leonard@eng.ox.ac.uk) \\ University of Oxford https://orcid.org/0000-0002-7072-9150 \\ Scot Wheeler \\ University of Oxford https://orcid.org/0000-0001-7335-5919 \\ Malcolm McCulloch \\ University of Oxford https://orcid.org/0000-0001-5378-1128
}

\section{Short Report}

Keywords: Rural electrification, Kenya, Geospatial analysis, Spatial policy, Energy policy, Mutli-tier framework

Posted Date: October 28th, 2021

DOI: https://doi.org/10.21203/rs.3.rs-1023333/v1

License: (c) (i) This work is licensed under a Creative Commons Attribution 4.0 International License. Read Full License 


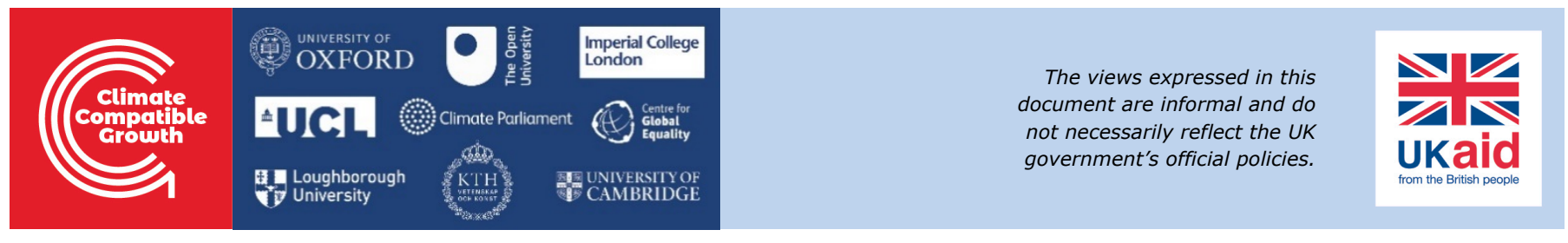

\title{
Rapid Electrification in Kenya: Progress, challenges, and practical geospatial solutions
}

\author{
Alycia Leonard*1, Scot Wheeler ${ }^{1}$, and Malcolm McCulloch ${ }^{1}$
}

\section{Key Messages}

- Rural electrification can be improved through geospatial policy interventions.

- Existing geospatial data can be used to better estimate electricity demand, target best-fit electrification technologies, and implement incentives to encourage universal access.

- $\quad$ Service for existing customers can be improved by geotagging customer records, fault reports, maintenance work, and other operational data.

- Kenya illustrates many typical rural electrification challenges and the potential of geospatial solutions.

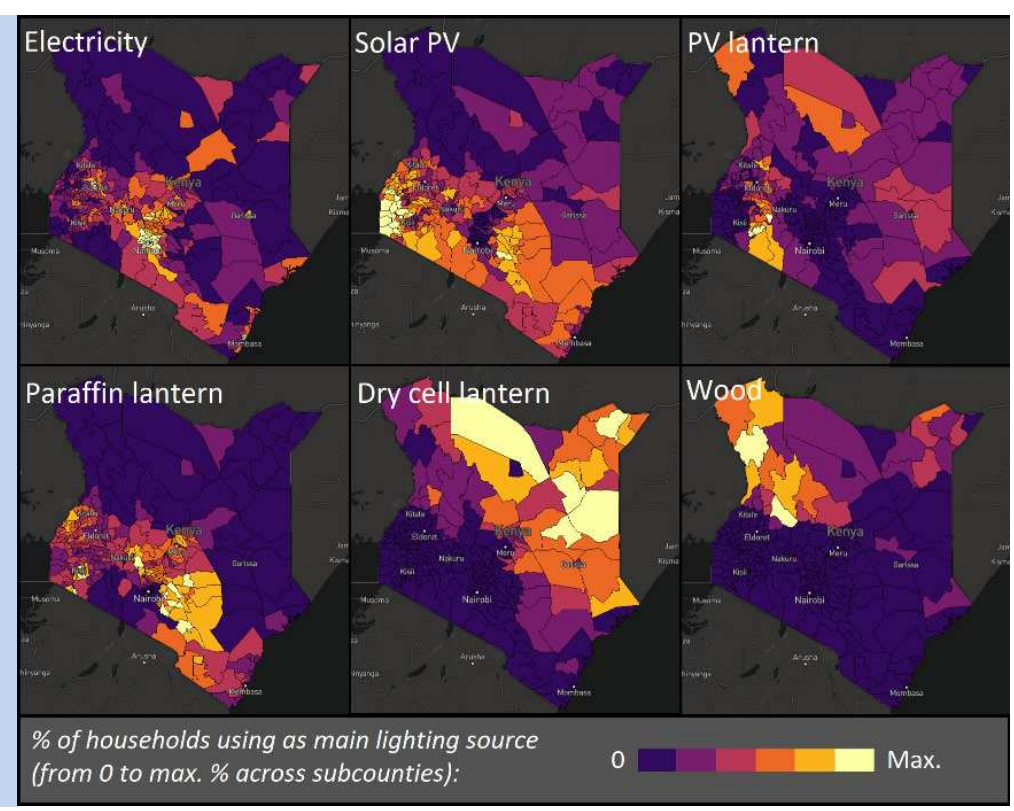

Figure 1: Prevalence of different lighting technologies across Kenyan sub-counties. Energy usage and choices vary geographically. So, geospatially informed electrification strategies and policies are needed [1, 2].

\section{Introduction}

This brief argues that by leveraging existing geospatial data and methods, we can solve persistent rural electrification challenges through geospatially informed policy interventions.

Rapid rural electrification is challenging, particularly in low- and middle-income countries (LMICs) trying to simultaneously electrify, develop, and avoid or reduce carbon emissions. There is no playbook to electrify under these constraints, and no time to wait for one to be established, given the time pressures of the Sustainable Development Goals [3] and the ongoing climate crisis [4]. Policymakers and power system stakeholders in LMICs must creatively work towards sustainable electrification to improve welfare and climate resilience despite ambiguity and recurring challenges.

Kenya is a salient example of rapid electrification despite challenges. Electricity access there has increased from $2 \%$ in 1994 to $70 \%$ today. This compares favourably to neighbouring Uganda (41\%) and Tanzania (38\%), and to the subSaharan African average (47\%) [5]. This progress has transpired despite persistent financial, operational, regulatory, and socio-political issues, providing examples of more and less effective mitigation strategies.

We evaluate Kenya's rapid rural electrification as a case study to demonstrate the potential of geospatial data and solutions to untangle complex electrification problems in LMICs. Below, we detail our methods, results in the Kenyan context, and recommendations for rapidly electrifying LMICs.

\section{Analysis Methods}

Rural electrification challenges in Kenya were identified through interviews with ten power sector stakeholders spanning academic, industrial, and civil society organizations, as well as through extensive policy and literature review. Challenges identified were analysed using the Multi-Tier Matrix for Measuring Access to Household Electricity Supply [6], which links sector issues to attributes of electric service and centres the end-user in the analysis. Geospatial implications and causes were identified. Solutions were recommended based on real-world and academic best-practice. 


\section{Results}

The following key challenges to rural electrification were identified in the Kenyan context:

Demand overestimation, particularly amongst rural residential customers, has led to underutilized distribution infrastructure and oversized generation capacity.

Unaffordability and inconvenience of on-grid electricity, driven by high connection charges and long rural connection delays, and fluctuating and opaque tariffs, causes consumers to pursue capacity-limited options like solar home systems (SHS).

Difficulties establishing a business, including land ownership problems, cross-border trade issues, and regulatory hurdles, discourage private entities from entering the energy market.

Unrealistic economic expectations of rapid rural electrification profitability, despite strong historical precedent for electrification of dispersed populations being slow and expensive [7], leading to hyper-competitive attitudes and inefficiencies which inhibit best-fit technology dissemination.

\section{Underservice of vulnerable populations,} including long-term refugees and various rural tribes, perpetuates the access gap amongst already marginalized communities.

Mistrust and corruption, particularly in rural areas with vulnerable populations who may struggle to navigate bureaucratic connection processes, lead to resentment and avoidance of the grid.

Frequent service inconsistencies, including blackouts and voltage issues, make people less likely to connect to the grid, reduce business productivity, and damage equipment, driving anchor clients off-grid.

Slow transition to electric cooking and transport despite numerous potential health benefits represents a missed opportunity to boost rural load while reducing emissions and improving gender equity.

As energy use in Kenya varies geospatially (see Figure 1), each of these challenges can be understood to have geospatial roots and solutions, as detailed below.

\section{Recommendations: Kenya}

Geospatial data and tools can be used to mitigate many rural electrification challenges, including and beyond those identified above. For Kenya, the geospatial roots of identified challenges are detailed in Table 1, alongside potential prevention/mitigation strategies or solutions and implementors for each.

Table 1: Specific rural electrification challenges and geospatial solutions identified in the Kenyan context.

\begin{tabular}{|c|c|c|c|}
\hline Challenge & Geospatial roots & $\begin{array}{l}\text { Specific geospatial prevention, mitigation, or } \\
\text { solution strategies }\end{array}$ & Implementors* \\
\hline $\begin{array}{l}\text { Demand } \\
\text { overestimation }\end{array}$ & $\begin{array}{l}\text { Infrastructure oversized for regional } \\
\text { demands. }\end{array}$ & Model demand geospatially. & $\begin{array}{l}\text { MoE, KenGen, KP, } \\
\text { KETRACO, REREC }\end{array}$ \\
\hline \multirow{3}{*}{$\begin{array}{l}\text { Unaffordability } \\
\text { and } \\
\text { inconvenience }\end{array}$} & \multirow{2}{*}{$\begin{array}{l}\text { Regional variance of price and availability } \\
\text { of energy technologies. }\end{array}$} & Analyse geospatial fuel and SHS availability/costs. & MoE \\
\hline & & Implement geospatially scaled subsidies. & EPRA, KP \\
\hline & Rural delays in grid connection. & Map connection delays to reallocate personnel. & KP \\
\hline \multirow{2}{*}{$\begin{array}{l}\text { Difficulties } \\
\text { establishing a } \\
\text { business }\end{array}$} & $\begin{array}{l}\text { Property registration and cross-border } \\
\text { trade difficulties. }\end{array}$ & $\begin{array}{l}\text { Implement a geotagged property registration } \\
\text { database. }\end{array}$ & MoLPP \\
\hline & $\begin{array}{l}\text { Regulation prohibiting multiple } \\
\text { co-located providers. }\end{array}$ & Publish provider coverage maps. & MoE, EPRA, MoLPP \\
\hline \multirow{3}{*}{$\begin{array}{l}\text { Unrealistic } \\
\text { economic } \\
\text { expectations }\end{array}$} & $\begin{array}{l}\text { Overestimated profitability of } \\
\text { electrification in disperse rural settings. }\end{array}$ & $\begin{array}{l}\text { Use geographically similar countries as precedent } \\
\text { for strategy and planning. }\end{array}$ & MoE，REREC \\
\hline & $\begin{array}{l}\text { Inefficient duplication of geospatial } \\
\text { modelling and data gathering. }\end{array}$ & Foster an open data ecosystem. & MoE, KNBS \\
\hline & $\begin{array}{l}\text { Hyper-competition in dense low-hanging } \\
\text { fruit markets. }\end{array}$ & $\begin{array}{l}\text { Implement incentives for dissemination of best-fit } \\
\text { technologies. }\end{array}$ & MoE, EPRA \\
\hline \multirow{2}{*}{$\begin{array}{l}\text { Underservice of } \\
\text { vulnerable } \\
\text { populations }\end{array}$} & $\begin{array}{l}\text { Energy norms driven by local culture, land } \\
\text { use, and movement. }\end{array}$ & $\begin{array}{l}\text { Monitor population dispersion and movement via } \\
\text { satellite imagery to understand best-fit solutions. }\end{array}$ & KNBS \\
\hline & $\begin{array}{l}\text { Dependence on local availability of } \\
\text { biomass (e.g., refugees, remote rural). }\end{array}$ & $\begin{array}{l}\text { Integrate costs of ecological degradation into } \\
\text { financial viability analysis for electrification. }\end{array}$ & MoE, KP, REREC \\
\hline \multirow{2}{*}{$\begin{array}{l}\text { Mistrust and } \\
\text { corruption }\end{array}$} & $\begin{array}{l}\text { Lack of managerial oversight or } \\
\text { accountability in proximity to end-user. }\end{array}$ & Implement geotagged complaint system. & KP \\
\hline & $\begin{array}{l}\text { Spatial misallocation of operations and } \\
\text { maintenance resources. }\end{array}$ & $\begin{array}{l}\text { Track connection and maintenance delays } \\
\text { geographically and reallocate as necessary. }\end{array}$ & $\mathrm{KP}$ \\
\hline \multirow{2}{*}{$\begin{array}{l}\text { Frequent service } \\
\text { inconsistencies }\end{array}$} & $\begin{array}{l}\text { Lack of information about high-frequency } \\
\text { event areas. }\end{array}$ & $\begin{array}{l}\text { Implement geotagged power system management } \\
\text { system. }\end{array}$ & $\begin{array}{l}\text { KP, KETRACO, } \\
\text { KenGen, MoE }\end{array}$ \\
\hline & $\begin{array}{l}\text { Improperly allocated operations and } \\
\text { maintenance resources. }\end{array}$ & $\begin{array}{l}\text { Track incidents geospatially, reallocate } \\
\text { resources to high-frequency areas. }\end{array}$ & $\begin{array}{l}\text { KP, KETRACO, } \\
\text { KenGen }\end{array}$ \\
\hline \multirow{2}{*}{$\begin{array}{l}\text { Slow transition } \\
\text { to electric } \\
\text { cooking and } \\
\text { transport }\end{array}$} & $\begin{array}{l}\text { Affordability of electricity compared to } \\
\text { fuels varies regionally. }\end{array}$ & $\begin{array}{l}\text { Incentivize uptake through geospatially informed } \\
\text { subsidy. }\end{array}$ & EPRA, MoE \\
\hline & $\begin{array}{l}\text { Cultural expectation to use dirty fuels or } \\
\text { biomass - energy norms vary regionally. }\end{array}$ & $\begin{array}{l}\text { Integrate costs of ecological degradation into } \\
\text { financial viability analysis for electrification. }\end{array}$ & MoE, KP, REREC \\
\hline
\end{tabular}




\section{Recommendations: General}

Generalizing on the Kenyan case study, four underlying geospatial interventions are recommended to mitigate perennial rural electrification challenges in LMICs:

1) Model demand geospatially: This can help to avoid oversizing and underuse issues as experienced in Kenya. Data requirements include population density/location, demographics, and knowledge of dominant industries. These can be obtained from the census, open data sources (e.g., OpenStreetMap, High-Resolution Settlement Layer), or large surveys (e.g., Living Standards Measurement Survey, Multiple Indicator Cluster Survey).

2) Target technologies for local suitability: This can help to avoid technology mismatch and underservice issues as experienced amongst various tribes and refugees in Kenya. Data requirements include geospatial demand data (see above), renewable resource potentials (available online e.g., from Renewables.Ninja) and knowledge on population motion (evaluated from satellite imagery).
3) Manage power systems with a Geographic Information System (GIS): This can help to avoid geospatial misallocation of operational and maintenance resources, prevent delays and service issues, and resolve faults quickly. This requires data on fault locations, which can be collected by maintenance staff using various free location recording apps. An interface for customers to record geotagged issues should be made available. These data can be integrated, alongside system infrastructure data (i.e., shapefiles), in (minimally) a GIS, such as QGIS or (optimally) a system management program like Odyssey.

4) Incentivize and subsidize regional needs: This can help to avoid competitive inefficiencies preventing universal access by making it financially viable for best-fit technologies to reach appropriate consumers. Planning such subsidies will require geospatial records of off- and on-grid provider coverage in a coherent database. It will also require geospatial cost data throughout energy supply chains, including fuels and equipment. Such an intervention can encourage the private sector to fill hard-to-reach gaps.

\footnotetext{
* Table 1 notes: MoE = Ministry of Energy; KenGen = Kenya Electricity Generating Company; KP = Kenya Power; EPRA = Energy and Petroleum Regulatory Authority; MoLPP = Ministry of Lands and Physical Planning; KNBS = Kenya National Bureau of Statistics; REREC
} $=$ Rural Electrification and Renewable Energy Corporation; KETRACO = Kenya Electricity Transmission Company

\section{References}

[1] Kenya National Bureau of Statistics (KNBS). (2019). Kenya Population and Housing Census Volume IV: Distribution of Population by Socio-Economic Characteristics. Accessed Through Energy Access Explorer, 28 ${ }^{\text {th }}$ June 2021. www.energyaccessexplorer.org.

[2] EED Advisory Kenya \& World Resources Institute (WRI). (2020). Population Census Data Report: Lighting, Cooking \& Household Assets Data. Accessed through Energy Access Explorer, 28 ${ }^{\text {th }}$ June 2021. www.energyaccessexplorer.org

[3] United Nations (UN). The Sustainable Development Goals Report 2020. United Nations Publications, New York, United States of America. https://unstats.un.org/sdgs/report/2020/TheSustainable-Development-Goals-Report-2020.pdf

[4] Intergovernmental Panel on Climate Change (IPCC). (2018). Global Warming of $1.5^{\circ} \mathrm{C}$. An IPCC Special Report. World Meteorological Organization, Geneva, Switzerland. Available: https://www.ipcc.ch/sr15/
[5] World Bank. Access to electricity (\% of population). Accessed $28^{\text {th }}$ June 2021 from: https://data.worldbank.org/indicator/EG.ELC.ACCS. ZS?locations=UG-KE-TZ-ZG

[6] Bhatia, M. \& Angelou, N. (2015). Beyond Connections: Energy Access Redefined. Technical Report 008/15, Energy Sector Management and Assistance Program (ESMAP). The World Bank Group, Washington DC, United States of America. Available:

https://openknowledge.worldbank.org/bitstream/ha ndle/10986/24368/Beyond0connect0d000technical0 report.pdf?sequence $=1$ \&isAllowed $=y$

[7] Pellegrini, L., \& Tasciotti, L. (2013, March). Rural electrification now and then: comparing contemporary challenges in developing countries to the USA's experience in retrospect. In Forum for Development Studies (Vol. 40, No. 1, pp. 153-176). Routledge.

\section{Notes}

Climate Compatible Growth (CCG) programme: CCG is funded by the UK's Foreign Development and Commonwealth Office (FCDO) to support investment in sustainable energy and transport systems to meet development priorities in the Global South.

\author{
Author Information: \\ Affiliations \\ ${ }^{1}$ Energy and Power Group, Department of Engineering \\ Science, University of Oxford, Oxford, United Kingdom \\ *Corresponding author \\ Email address: alycia.leonard@eng.ox.ac.uk
}




\section{Figures}

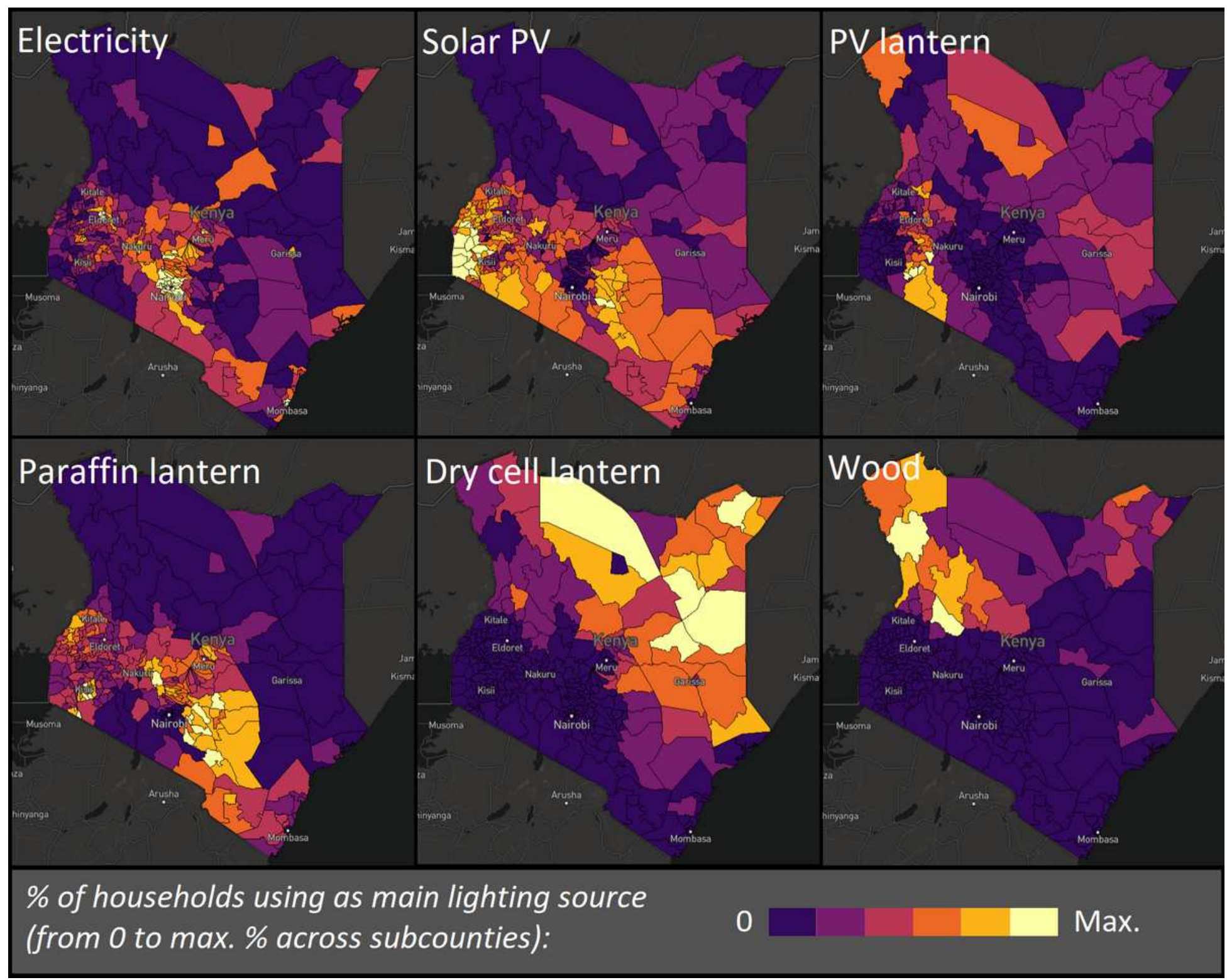

\section{Figure 1}

Prevalence of different lighting technologies across Kenyan sub-counties. Energy usage and choices vary geographically. So, geospatially informed electrification strategies and policies are needed [1, 2]. 